Lax enforcement of animal rules alleged

\section{- Contraventions found at MRC institute}

\section{- Home Office inquiry launched}

London

Allegations of serious misconduct by a senior scientist at the UK Medical Research Council (MRC)'s National Institute for Medical Research (NIMR) in London have brought into question the effectiveness with which Britain's rules on animal experimentation, substantially reformed in 1986, are being enforced.

A Scottish animal rights group, Advocates for Animals, has submitted to the Home Secretary, David Waddington, a report on experiments done by Professor Wilhelm Feldberg, an 89-year-old researcher, and his assistant, John Stean. The report, which includes videotaped evidence, catalogues a number of alleged contraventions of the rules under which a Home Office licence to perform animal experiments is granted. The dossier of evidence was compiled by two animal rights activists, who obtained invitations to Feldberg's laboratory by deception. One, Melody MacDonald, posed as Feldberg's biographer for two years, while the other, Michael Huskisson, videotaped experiments over five months under the pretence that the tapes would be used to teach US students. The pair approached Advocates for Animals with their evidence last month.

The tapes show rabbits struggling, apparently under only light anaesthesia, while surgical procedures are carried out and their body surfaces are heated to over $130{ }^{\circ} \mathrm{C}$. Feldberg's work concerned the mechanisms by which blood sugar levels become raised after heating. Animals were also left unattended during experiments, according to Les Ward, director of Advocates for Animals.

A Home Office statement says the allegations are taken "very seriously" and that its Animal Procedures Committee will be asked to review the general lessons to be learned from the case in order to determine whether Feldberg's alleged misconduct is an isolated instance or an indication that the 1986 Animals (Scientific Procedures) Act is being poorly implemented.

The 1986 Act reformed legislation which had stood since 1876 , and instituted a stricter system of licences for individual procedures, projects and scientists. Its enforcement relies on monitoring by Home Office inspectors and by named people within laboratories who are made responsible for the day-to-day care of experimental animals.

Clive Hollands, a previous director of
Advocates for Animals (then known as the Scottish Society for the Prevention of Vivisection), advised the government during the drafting of the act. His participation angered most other factions within the animal rights movement. Ward says that Advocates for Animals made their allegations public to draw attention to the failure to enforce the act, and adds that the group feels that the trust it showed by supporting the act has been betrayed.

Michael Balls, from the Fund for the Replacement of Animals in Medical Experiments, also advised the government on the 1986 Act. He says his commitment to the act is unaffected by the allegations. But he acknowledges that questions must now be raised concerning the "universality" of its enforcement. There may well be other individuals in violation of their licences, Balls says, but he adds that "I don't believe their number is great"

Balls believes that there are enough Home Office inspectors to enforce the act (currently 20, with nearly 18,000 licence holders). Animal researchers are "people with integrity", he says, and any infringements of the 1986 Act are usually the result of misinterpretation, rather than "wilful attempts to avoid the law". But one biomedical scientist, who wished to remain anonymous, questioned whether some inspectors have sufficient understanding of modern scientific procedures.

Whatever the general lessons to be learned from the case, an inquiry is to be launched into arrangements at NIMR. The roles of senior NIMR staff, Home Office inspectors, the day-to-day animal care officer and the veterinarian responsible for regular checks on the laboratory will come under scrutiny. Balls says that other scientists at NIMR had a "moral responsibility to protect [Feldberg] from himself". In the videotapes, Feldberg is seen as a frail old man, whose eyesight, by his own admission, is failing him. There is concern that Feldberg's eminence he is a fellow of the Royal Society and was recently awarded a medal by the British Pharmacological Society - may have exempted him from proper monitoring.

Staff at NIMR have been instructed to refer questions to the MRC's head office. The MRC says that its investigation will include a review of procedures for monitoring the continued competence of researchers to work on animals. Dai Rees, MRC secretary and a former director of NIMR, adds that the MRC inquiry will not be a solely internal affair: "credible independent opinion" will be consulted.

The MRC supported Feldberg's work up to 30 April this year, but had decided to discontinue his grant on 6 March. After hearing this, Feldberg is believed to have asked for permission to continue his work without an MRCstipend. Nick Winterton, head of MRC's secretariat, says that NIMR director John Skehel was already intending to wind the work up, but acknowledges that this process may have been accelerated by the allegations. Feldberg and Stean, who is also over normal retirement age, returned their licences to the Home Office the day after the Advocates for Animals evidence had been brought to the attention of the Home Office.

Peter Aldhous

\title{
Paul Ehrlich Institute opened in Langen
}

\section{Munich}

RESEARCHERS from the United States, Israel and Europe converged on Langen, West Germany, two weeks ago to celebrate the official opening of the new Paul Ehrlich

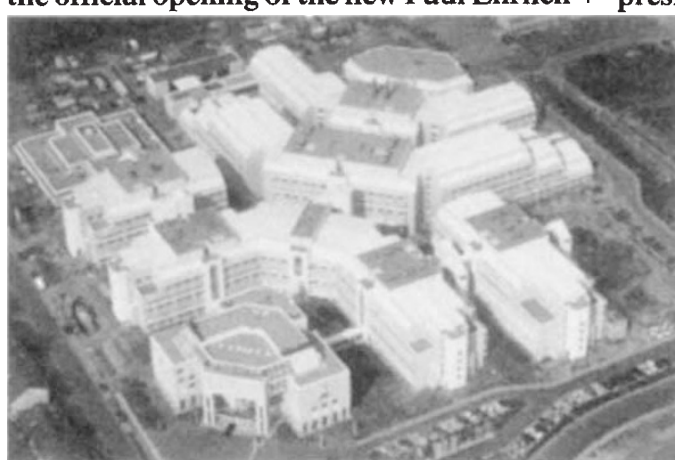

The building, which has a shape reminiscent of an antibody molecule, has taken six years and DM335 million ( $\$ 200$ million) to construct. It is still not complete. PEI president Reinhard Kurth hopes to bring all 320 employees, including $\mathbf{7 0}$ scientific staff members, from the cramped quarters in Frankfurt to suburban Langen by the end of 1990.

PEI was established in Frankfurt in 1899 as the "State Institute for Experimental Therapy" by and for Paul Ehrlich (1854-1915), who was one of the founders of modern immunology and originator of chemotherapy. Ehrlich, a German Jewish physician from Breslau, Silesia, achieved recognition for inventing

Institute (PEI) which serves both as a research centre and the federal office for sera and vaccines.
Salvarsan, an arsenic-based drug that was the first cure for syphilis. He won the Nobel prize in 1908 .
Steven Dickman 